\title{
Arbeidsmarktprognoses Noordwest Veluwe 2017-2022
}

Citation for published version (APA):

Peeters, T., \& Cörvers, F. (2018). Arbeidsmarktprognoses Noordwest Veluwe 2017-2022. ROA. ROA Fact Sheets No. 010G https://doi.org/10.26481/umarof.2018010G

Document status and date:

Published: 01/01/2018

DOI:

10.26481/umarof.2018010G

Document Version:

Publisher's PDF, also known as Version of record

\section{Please check the document version of this publication:}

- A submitted manuscript is the version of the article upon submission and before peer-review. There can be important differences between the submitted version and the official published version of record.

People interested in the research are advised to contact the author for the final version of the publication, or visit the DOI to the publisher's website.

- The final author version and the galley proof are versions of the publication after peer review.

- The final published version features the final layout of the paper including the volume, issue and page numbers.

Link to publication

\footnotetext{
General rights rights.

- You may freely distribute the URL identifying the publication in the public portal. please follow below link for the End User Agreement:

www.umlib.nl/taverne-license

Take down policy

If you believe that this document breaches copyright please contact us at:

repository@maastrichtuniversity.nl

providing details and we will investigate your claim.
}

Copyright and moral rights for the publications made accessible in the public portal are retained by the authors and/or other copyright owners and it is a condition of accessing publications that users recognise and abide by the legal requirements associated with these

- Users may download and print one copy of any publication from the public portal for the purpose of private study or research.

- You may not further distribute the material or use it for any profit-making activity or commercial gain

If the publication is distributed under the terms of Article $25 \mathrm{fa}$ of the Dutch Copyright Act, indicated by the "Taverne" license above, 
Maastricht University $\&$ ROA

\section{Arbeidsmarktprognoses Noordwest Veluwe 2017-2022}

Tim Peeters

Frank Cörvers

\section{ROA Fact Sheet}

ROA-F-2018/10G

Researchcentrum voor Onderwijs en Arbeidsmarkt | ROA Research Centre For Education and the Labour Market / ROA 


\section{Arbeidsmarktprognoses Noordwest Veluwe 2017-2022}

Inleiding

Als onderdeel van het Project Onderwijs-Arbeidsmarkt (POA) stelt het ROA sinds 2013 tweejaarlijkse regionale arbeidsmarktprognoses op die tegemoet komen aan de toenemende belangstelling voor regionale arbeidsmarktinformatie. Binnen dit kader past ook voorliggende factsheet met arbeidsmarktprognoses voor de regio Noordwest Veluwe. Deze prognoses bestrijken de periode 2017-2022 en worden weergegeven voor 24 opleidingscategorieën die verdeeld zijn over zes opleidingsniveaus. Waar mogelijk worden de prognoses vergeleken met deze voor Gelderland als geheel, en wordt er een relatie gelegd met zowel de sector- als opleidingsspecialisatie van de werkgelegenheid in de verschillende regio's. De interpretatie van de prognoses gebeurt steeds vanuit het perspectief van schoolverlaters en werkzoekenden.

De prognoses voor de hele provincie Gelderland evenals een leeswijzer kunnen gevonden worden in de factsheet met nummer ROA-F-20I8/IO. Onderstaande kaart geeft weer hoe Gelderland is samengesteld uit de verschillende arbeidsmarktregio's, en de overzichtstabel laat de verschillende gemeenten zien die in Noordwest Veluwe gelegen zijn. Zie ten slotte Tekstbox I voor definities van de in deze factsheet gebruikte variabelen.

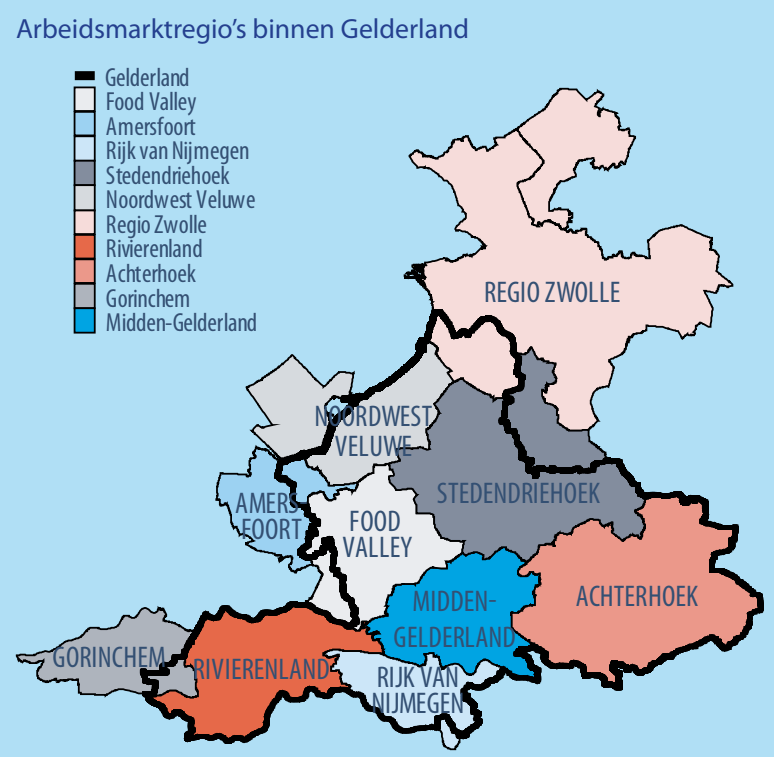

Gemeenten in Noordwest Veluwe

\begin{tabular}{l|l|}
\hline Gelderse gemeenten & Niet-Gelderse gemeenten \\
\hline Elburg & Zeewolde \\
\hline Ermelo & \\
\hline Harderwijk & \\
\hline Nunspeet & \\
\hline Putten & \\
\hline
\end{tabular}

\section{Prognoses en actuele arbeidsmarktcijfers naar} opleidingsniveau

Noordwest Veluwe is met 69.000 werkenden veruit de kleinste van de Gelderse arbeidsmarktregio's. Met een ITA van I,OI over alle opleidingsniveaus heen wordt net als in Gelderland ook in deze arbeidsmarktregio de komende zes jaar op geaggregeerd niveau min of meer een arbeidsmarktevenwicht verwacht. Voor mbo 2/3 (ITA van I,I4) en mbo 4 (ITA van I,II) wordt echter een aanbodoverschot voorzien dat groter is dan in de andere arbeidsmarktregio's. Dit wordt voornamelijk gedreven door een relatief grote verwachte instroom van mbo-schoolverlaters. De vooruitzichten voor schoolverlaters en werkzoekenden van het wo zijn met een ITA van o,8I zeer goed. Hierbij dient echter opgemerkt te worden dat die zeer gunstige ITA voor een belangrijk deel wordt veroorzaakt door enkele positieve uitschieters bij de schattingen voor de onderliggende wo-opleidingscategorieën als gevolg van een lage celvulling.

Opvallend is ook dat schoolverlaters van het basisonderwijs en vmbo goede arbeidsmarktperspectieven hebben volgens de ITA. Deze gunstige vooruitzichten dienen echter met enige voorzichtigheid geïnterpreteerd te worden. Een aanzienlijk deel van de vraag naar personen met basisonderwijs of vmbo als opleidingsachtergrond heeft namelijk betrekking op laagbetaalde en kleine banen. Dit kan afgeleid worden van het relatief lage uurloon (13,7 euro), het lage gemiddeld aantal gewerkte uren per week $(28,4)$ en het hoge aandeel van studenten en scholieren (2I\%). Bovendien gaat het vaak om flexibele banen met weinig doorgroeimogelijkheden. Enerzijds blijkt dit uit het lage percentage dat voltijds en vast in dienst is. Anderzijds komt dit ook tot uiting in het slechte loopbaanperspectief. De variabele "typering loopbaan", die per opleidingsniveau de loongroei tussen ca. 25 en 45 jaar (berekend voor Nederland als geheel) weergeeft in 20I6, is namelijk het minst gunstig voor laagopgeleiden, en het meest gunstig voor havo/vwo. ${ }^{1}$ Deze laatste groep bestaat mogelijk deels uit mensen die geen hogere opleiding hebben afgemaakt omdat ze door hun persoonlijke capaciteiten uitstekende kansen op de arbeidsmarkt hadden.

Verder is van belang dat de groep van laagopgeleiden met basisonderwijs of vmbo heel heterogeen is: niet alleen scholieren, maar ook voortijdig schoolverlaters zonder

I De indicator voor loopbaanperspectief wordt berekend aan de hand van het verschil in bruto uurloon van werkenden in de leeftijdsgroep 20-29 jaar en 40-49 jaar. Voor een argumentatie, zie Fouarge, D., Kriechel, B., \& Dohmen, T. (20I4), Occupational sorting of school graduates: The role of economic preferences, Journal of Economic Behavior \& Organization, 106, 335-351. 
startkwalificatie (minimaal mbo 2 of havo), schoolverlaters van het speciaal onderwijs en arbeidsgehandicapten. Bij het aangegeven goede arbeidsmarktperspectief is geen rekening gehouden met de mogelijke sociale, fysieke en cognitieve beperkingen van mensen binnen deze groep.

Met betrekking tot de actuele arbeidsmarktindicatoren valt op dat alle opleidingsniveaus afgezien van wo een grotere werkzaamheid kennen dan in Gelderland als geheel. Verder is het aandeel van de werkenden met een voltijdse aanstelling onder mbo 4-gediplomeerden (45\%) lager dan het Gelderse gemiddelde voor deze groep (53\%), en geldt het omgekeerde voor havo/vwo $39 \%$ in Noordwest Veluwe tegenover $33 \%$ in de provincie).

\section{Sectorspecialisatie}

Figuur I geeft voor 2I bedrijfssectoren weer hoe het aandeel van het aantal werkenden ${ }^{2}$ in een sector in Noordwest Veluwe zich verhoudt tot het aandeel van die sector in Nederland. Dit laat toe om sectoren te identificeren waarin Noordwest Veluwe gespecialiseerd is. De oranje stippen geven bovendien de sectorspecialisatie van Gelderland als geheel weer. Noordwest Veluwe heeft relatief veel werkgelegenheid in de energiesector, de bouwnijverheid en de welzijnssector ten opzichte van Nederland en Gelderland. De grootste specialisatie geldt echter voor de voedings- en genotmiddelenindustrie, die een werkgelegenheidsaandeel heeft dat bijna twee maal groter is dan het Nederlandse. De aandelen van de andere industriesectoren zijn dan weer beduidend kleiner dan zowel de Nederlandse als de Gelderse. Andere sectoren met relatief kleine werkgelegenheidsaandelen zijn ten slotte de detailhandel, specialistische zakelijke dienstverlening, verhuur en overige zakelijke dienstverlening en cultuur, sport en recreatie.

\section{Arbeidsmarktperspectieven naar opleidingscategorie}

De prognoses naar opleidingsniveau uit de eerste paragraaf kunnen verder uitgesplitst worden naar opleidingscategorie. Dit is weergegeven in Figuur 2, die per opleidingscategorie binnen het lager en middelbaar (beroeps)onderwijs toont hoe de totale arbeidsvraag en het totale arbeidsaanbod zich naar verwachting de komende zes jaar in Noordwest Veluwe zullen verhouden. Figuur 3 doet hetzelfde voor het hoger onderwijs.

De kleuren bakenen de gebieden af die corresponderen met de vijf ITA-typeringen (zie Tekstbox I) voor schoolverlaters en werkzoekenden, gaande van slecht (rood en ITA > I,I5) tot zeer goed (grijs en ITA $\leq 0,85$ ). Deze kunnen

2 Gebaseerd op de werkzame beroepsbevolking uit de Enquête Beroepsbevolking (EBB), inclusief zelfstandigen. geïnterpreteerd worden als kwalitatieve aanduidingen van de toekomstige arbeidsmarktperspectieven. Voor de punten op de middelste diagonale lijn zijn verwachte vraag en aanbod aan elkaar gelijk, wat correspondeert met een ITA gelijk aan I,oo. Bijvoorbeeld, voor hbo onderwijs bedragen het totale aanbod en de totale vraag over zes jaar respectievelijk (afgerond) I5\% en $29 \%$. Deze waarden impliceren een ITA van 0,89 , zodat hbo onderwijs zich bevindt in het donkerblauwe gedeelte met het perspectief "goed". 3 Merk op dat deze ITA een gemiddelde betreft van de opleidingscategorie hbo onderwijs, en dat er variatie kan bestaan in de arbeidsmarktperspectieven van de onderliggende opleidingstypes.

Afgezien van mbo 4 groen wordt voor elke mbo-opleidingscategorie de komende zes jaar een ITA groter dan I,OO verwacht. De minst gunstige perspectieven gelden daarbij voor schoolverlaters en werkzoekenden van mbo $2 / 3$ groen, mbo $2 / 3$ economie en mbo 4 zorg en welzijn. In alle drie de gevallen wordt dit hoofdzakelijk gedreven door een relatief grote verwachte arbeidsmarktinstroom van schoolverlaters. De perspectieven voor mbo 2/3- en mbo 4 techniek zijn daarentegen respectievelijk matig en redelijk.

Met betrekking tot de prognoses van de hogere opleidingen in Figuur 3 dient te worden opgemerkt dat het beperkte inwonersaantal van Noordwest Veluwe leidt tot lage celvulling voor de meeste hogere opleidingscategorieën. Dit leidt bijgevolg tot minder precieze schattingen, met name voor wo-opleidingscategorieën, en is de reden dat sommige opleidingscategorieën uit de figuur zijn weggelaten. ${ }^{4}$ Wo taal en cultuur, wo medisch en hbo techniek hebben alle drie zeer goede vooruitzichten, voornamelijk als gevolg van een relatief grote verwachte vraag. De minst gunstige arbeidsmarktperspectieven worden daarentegen voorzien voor hbo economie wegens een vrij lage uitbreidings- en vervangingsvraag. Aangezien er in tegenstelling tot de middelbare technische opleidingen voor hbo- en wo techniek wel een vraagoverschot wordt voorzien, impliceert dit dat de voor Noordwest Veluwe belangrijke voedings- en genotmiddelenindustrie, energiesector en bouwnijverheid naar verwachting voornamelijk wervingsproblemen zullen ondervinden voor hoger geschoold technisch personeel.

De berekening van de ITA is niet louter een deling van aanbod en vraag, aangezien teller en noemer nog dienen vermeerderd te worden met Ioo.

4 Het betreft wo techniek, wo landbouw en natuur en wo gedrag en maatschappij. In de totale regio Stedendriehoek en Noordwest Veluwe hebben schoolverlaters van deze opleidingscategorieen respectievelijk zeer goede, zeer goede en goede perspectieven. 
Relatie arbeidsmarktperspectieven en specialisatie naar opleiding

Figuur 4 toont de relatie tussen de verwachte arbeidsmarktperspectieven (ITA) voor de verschillende opleidingscategorieën over de periode 2017-2022 en de mate waarin Noordwest Veluwe in deze opleiding "gespecialiseerd" is. Deze laatste variabele is gelijk aan de ratio van het aandeel werkzame personen met een bepaalde opleidingscategorie die in Noordwest Veluwe wonen ten opzichte van het aandeel van die opleidingscategorie in het Nederlandse totaal. Indien de specialisatiecoëfficiënt voor een opleidingscategorie groter is dan I,oo, betekent dit dus dat Noordwest Veluwe in verhouding tot Nederland een groter aandeel van mensen met deze opleiding kent. Bijvoorbeeld, de opleidingsspecialisatiecoëfficiënt van I,I3 die hoort bij wo onderwijs impliceert dat het aandeel van deze opleidingscategorie in Noordwest Veluwe $13 \%$ groter is dan het aandeel van deze opleidingscategorie in Nederland als geheel.

De figuur toont een enigszins positief lineair verband, wat wil zeggen dat te veel arbeidsaanbod voor de toekomst samengaat met specialisatie in de werkgelegenheid voor deze opleidingen (doorgaans mbo-opleidingscategorieën), terwijl de arbeidsmarkttekorten vooral voorkomen voor opleidingen waarvoor Noordwest Veluwe niet bijzonder veel werkgelegenheid heeft (doorgaans wo-opleidingen). Toch hebben sommige opleidingscategorieën tegelijkertijd een lage specialisatiegraad en een relatief ongunstig arbeidsmarktperspectief (hoge ITA), zoals mbo $2 / 3$ - en mbo 4 economie. Een uitschieter aan de rechterzijde is de opleidingscategorie mbo 4 zorg en welzijn, die in Noordwest Veluwe verhoudingsgewijs bijna twee maal vaker voorkomt dan in Nederland.

Het minst gunstige arbeidsmarktperspectief op hbo-niveau geldt voor de categorie hbo economie, die in deze arbeidsmarktregio tevens verhoudingsgewijs iets meer gediplomeerde schoolverlaters telt dan in Nederland. Het omgekeerde geldt voor schoolverlaters van hbo techniek, die gunstige arbeidsmarktvooruitzichten hebben maar een relatief kleine werkzame beroepsbevolking voorstellen in deze arbeidsmarktregio. Afgezien van hbo techniek en hbo landbouw en natuur komen hbo-opleidingscategorieën echter ongeveer evenveel voor als in Nederland.

Tekstbox 1 Definities kernbegrippen

\begin{tabular}{|c|c|}
\hline Variabele & Definitie \\
\hline Uitbreidingsvraag & $\begin{array}{l}\text { Vraag naar nieuwe arbeidskrachten die ontstaat door de groei van de werkgelegenheid. Als er sprake is van een werkgelegenheidsdaling, is de uitbreidingsvraag } \\
\text { negatief. }\end{array}$ \\
\hline Vervangingsvraag & $\begin{array}{l}\text { Vervangingsvraag is de vraag naar nieuwe arbeidskrachten die ontstaat door bijvoorbeeld pensionering, (tijdelijke) uittreding vanwege zorgtaken, } \\
\text { arbeidsongeschiktheid, beroepsmobiliteit of doorstroom naar een andere opleiding. }\end{array}$ \\
\hline Arbeidsmarktuitstroom & De som van de vervangingsvraag en de negatieve uitbreidingsvraag. \\
\hline Arbeidsmarktinstroom & $\begin{array}{l}\text { De arbeidsmarktinstroom is het verwachte aanbod van nieuwe arbeidskrachten op de arbeidsmarkt. Deze is gebaseerd op de verwachte uitstroom van } \\
\text { schoolverlaters uit het initiële dag-, deeltijd-, niet-reguliere voltijdonderwijs en de beroepsgerichte volwasseneneducatie. Het weergegeven aanbod in de figuren } \\
2 \text { en } 3 \text { is de instroom. Gecorrigeerd voor mobiliteitsstromen tussen arbeidsmarktregio's. }\end{array}$ \\
\hline Baanopeningen & $\begin{array}{l}\text { Baanopeningen zijn de totale vraag naar nieuwkomers op de arbeidsmarkt, zoals deze is bepaald door de werkgelegenheidsgroei (positieve uitbreidingsvraag) en } \\
\text { de vervangingsvraag. In de figuren } 2 \text { en } 3 \text { is dit de vraag naar arbeid. }\end{array}$ \\
\hline ITA & $\begin{array}{l}\text { Indicator Toekomstige Arbeidsmarktperspectief (ITA) van schoolverlaters en werkzoekenden. Deze indicator is gelijk aan een deling van het verwachte aanbod } \\
\text { door de verwachte vraag tot 2022. Naarmate de waarde van de ITA hoger ligt, is er sprake van een slechter arbeidsmarktperspectief. Een waarde tussen 1,01 en } \\
1,05 \text { duidt op een evenwichtssituatie. }\end{array}$ \\
\hline Typering ITA & $\begin{array}{l}\text { Een kwalitatieve beschrijving van de ITA. ITA } \leq 0,85 \text { wordt als "zeer goed" getypeerd, ITA }>0,85 \text { en } \leq 1,00 \text { als "goed", ITA > 1,00 en } \leq 1,05 \text { als "redelijk", ITA > } \\
1,05 \text { en } \leq 1,15 \text { als "matig" en ITA }>1,15 \text { als "slecht". }\end{array}$ \\
\hline Typering loopbaan & $\begin{array}{l}\text { Het bruto uurloon van werkenden in de leeftijdsgroep 40-49 jaar ten opzichte van het bruto uurloon van werkenden in de leeftijdsgroep } 20-29 \text { jaar. Gemiddelde } \\
\text { cijfers voor Nederland in } 2016 .\end{array}$ \\
\hline Bruto uurloon & $\begin{array}{l}\text { Gemiddeld bruto uurloon van werknemers in euro's. Enquête Beroepsbevolking (EBB) gekoppeld aan het Sociaal Statistisch Bestand (SSB) van het jaar } 2016 . \\
\text { Gemiddelde cijfers voor Nederland in } 2016 .\end{array}$ \\
\hline Werkenden & Minimaal 1 uur werkzaam per week en in de leeftijd 15-74. Cijfers op basis van de Enquête Beroepsbevolking van het CBS. \\
\hline Werkzaamheid & Het percentage werkzaam is de werkzame beroepsbevolking als percentage van de potentiële beroepsbevolking (iedereen ouder dan 15 en jonger dan 75 jaar). \\
\hline Werkloosheid & $\begin{array}{l}\text { Percentage personen die geen betaald werk hebben, wel recent hebben gezocht en daarvoor direct beschikbaar zijn als percentage van de totale } \\
\text { beroepsbevolking (werkzaam en werkloos). }\end{array}$ \\
\hline Vast werk & Personen met een vast dienstverband. Percentage op basis van werknemers in de werkzame beroepsbevolking. \\
\hline Voltijds & Voltijdarbeid betreft personen die minstens 35 uur per week werkzaam zijn. Percentage op basis van de werkzame beroepsbevolking. \\
\hline Leeftijd & Gemiddelde leeftijd. \\
\hline Uren & Gemiddeld aantal uren werk per week. \\
\hline Student/scholier & Percentage van de werkenden met maatschappelijke positie student/scholier. \\
\hline Sectorspecialisatie & $\begin{array}{l}\text { De verhouding tussen het aandeel van het aantal werkenden in een sector in een bepaalde regio ten opzichte van het aandeel van die sector in Nederland. Een } \\
\text { sectorspecialisatiecoëfficiënt groter dan } 1 \text { impliceert dat het aandeel werkenden in de desbetreffende sector in de regio groter is dan in Nederland als geheel. }\end{array}$ \\
\hline Opleidingsspecialisatie & $\begin{array}{l}\text { De ratio van het aandeel personen met een bepaalde opleidingscategorie die wonen in een bepaalde regio ten opzichte van het aandeel van die } \\
\text { opleidingscategorie in het Nederlandse totaal. Indien de specialisatiecoëfficiënt voor een opleidingscategorie groter is dan 1, betekent dit dat de regio in } \\
\text { verhouding tot Nederland een groter aandeel van mensen met deze opleiding kent. }\end{array}$ \\
\hline
\end{tabular}


Tabel 1

Arbeidsmarktprognoses (2017-2022) en actuele arbeidsmarktcijfers (2015-2016) Noordwest Veluwe (NW) en Gelderland (GLD) naar opleidingsniveau*

\begin{tabular}{|c|c|c|c|c|c|c|c|}
\hline & bo/vmbo & havo/vwo & $m b o 2 / 3$ & mbo 4 & hbo & wo & totaal \\
\hline \multicolumn{8}{|l|}{ Prognoses } \\
\hline Uitbreidingsvraag (\%) & 0,5 & 0,4 & 0,7 & 0,9 & 0,6 & 1,4 & 0,7 \\
\hline Vervangingsvraag (\%) & 3,3 & 1,3 & 2,3 & 1,8 & 2,8 & 4,6 & 2,7 \\
\hline Arbeidsmarktinstroom (\%) & 2,0 & 1,6 & 5,1 & 3,8 & 3,4 & 1,0 & 3,0 \\
\hline ITA (NW) & 0,92 & 1,03 & 1,14 & 1,11 & 1,03 & 0,81 & 1,01 \\
\hline Typering ITA (NW) & goed & redelijk & matig & matig & redelijk & zeer goed & redelijk \\
\hline ITA (GLD) & 0,93 & 1,04 & 1,07 & 1,08 & 1,04 & 0,99 & 1,01 \\
\hline Typering ITA (GLD) & goed & redelijk & matig & matig & redelijk & goed & redelijk \\
\hline Typering loopbaan (NL)** & slecht & zeer goed & matig & redelijk & redelijk & goed & - \\
\hline \multicolumn{8}{|l|}{ Actuele indicatoren } \\
\hline Bruto uurloon $(\mathrm{NL})^{* *}$ & 13,7 & 17,3 & 17,7 & 19,2 & 25,1 & 34,7 & - \\
\hline Werkenden & 18.000 & 6.000 & 13.500 & 12.500 & 14.000 & 4.500 & 69.000 \\
\hline Werkzaamheid (\%) & 52 & 68 & 72 & 80 & 79 & 78 & 67 \\
\hline Werkloosheid (\%) & 3 & 3 & 3 & 3 & 2 & 4 & 3 \\
\hline Vast werk (\%) & 73 & 65 & 89 & 91 & 92 & 93 & 83 \\
\hline Voltijds (\%) & 47 & 39 & 52 & 45 & 50 & 64 & 49 \\
\hline Wekelijkse arbeidsduur (uur) & 28,4 & 25,3 & 31,6 & 29,8 & 32,3 & 34,5 & 30,2 \\
\hline Leeftijd werkenden (jaar) & 39,0 & 35,3 & 41,4 & 40,0 & 41,0 & 45,2 & 40,1 \\
\hline Student/scholier (\%) & 21 & 31 & 1 & 4 & 2 & 0 & 9 \\
\hline
\end{tabular}

"Prognoses als gemiddeld jaarlijks percentage van de werkzame beroepsbevolking in 2016; actuele indicatoren als percentage van de werkzame, totale of potentiële beroepsbevolking 2015-2016 (zie Tekstbox 1), tenzij anders aangegeven

*" Lonen voor Nederland in 2016

Figuur 1

Actuele sectorspecialisatie Noordwest Veluwe ten opzichte van Nederland en Gelderland (2015-2016)

Landbouw, bosbouw en visserij Voedings- en genotmiddelenindustrie Chemische industrie

Metaalindustrie

Overige industrie Energie Bouwnijverheid Detailhande

Groothandel

Vervoer en opslag Horeca

Informatie en communicatie

Financiële dienstverlening en onroerend goed

Specialistische zakelijke dienstverlening

Verhuur en overige zakelijke dienstverlening

Openbaar bestuur en overheidsdiensten Onderwijs Zorg Welzijn

Cultuur sport en recreati Overige dienstverlening, huishoudens en extraterritoriale organisaties

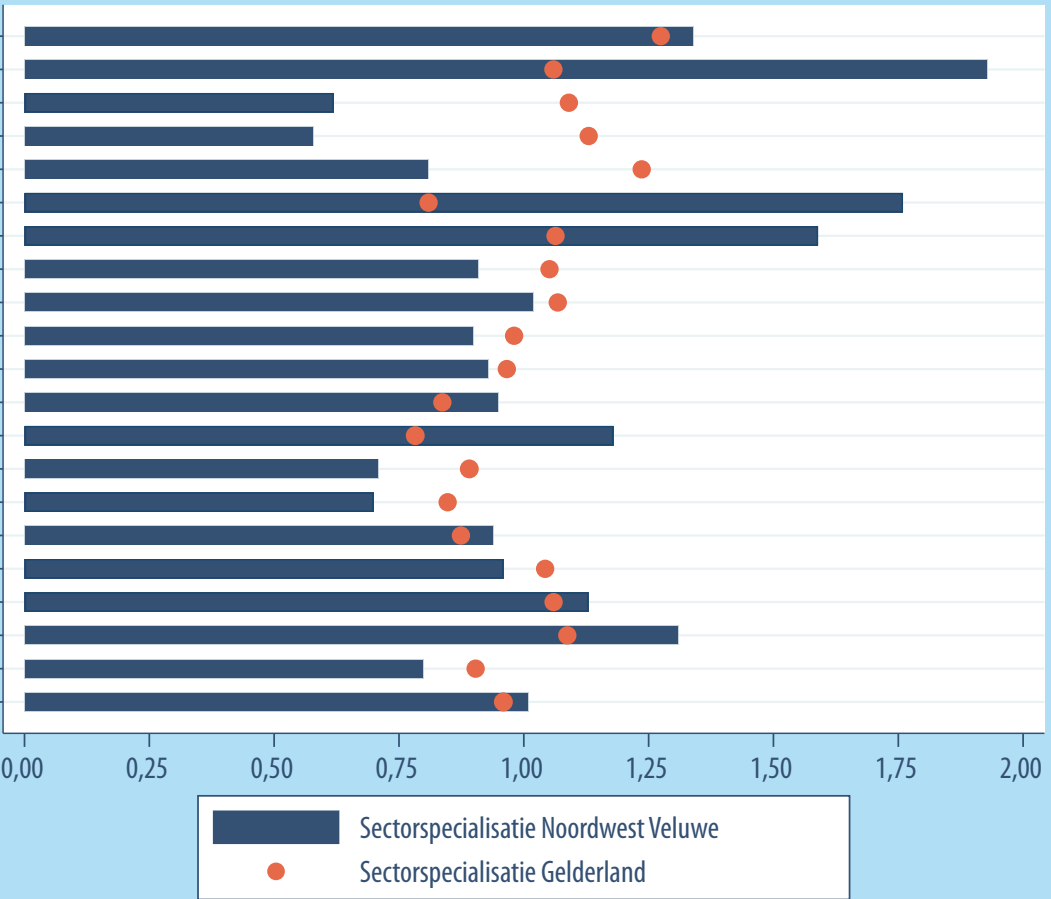




\section{Figuur 2}

Vraag en aanbod voor opleidingscategorieën lager/middelbaar (beroeps)onderwijs, Noordwest Veluwe (2017-2022)

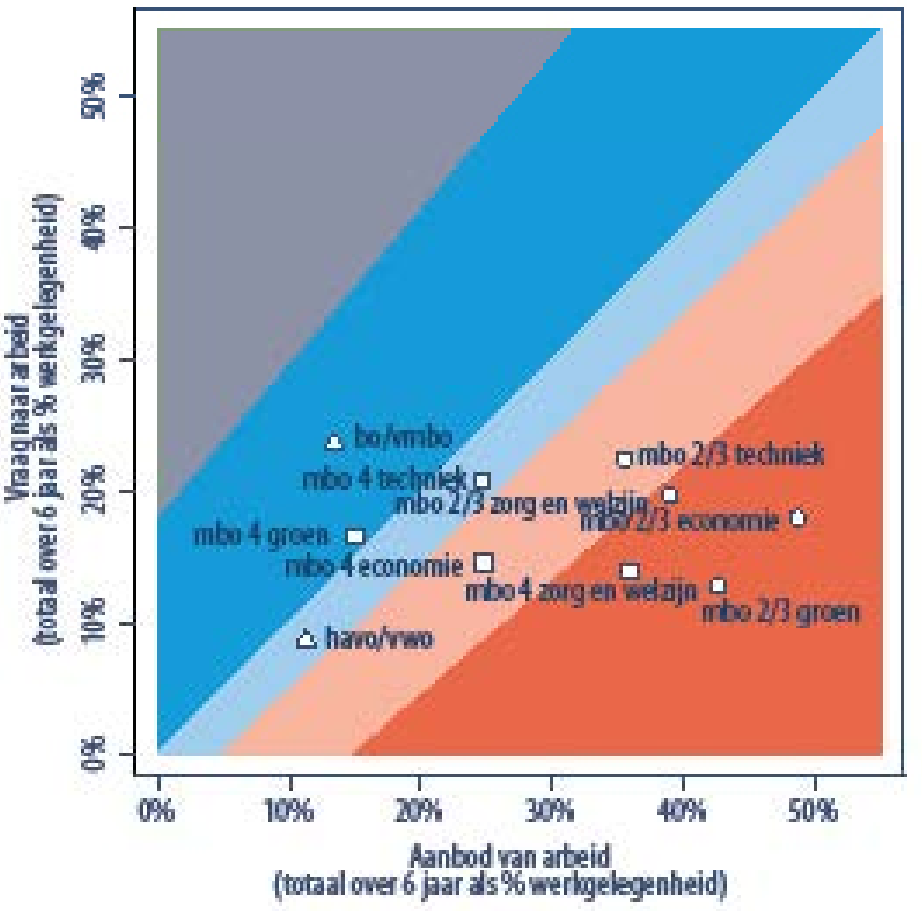

\begin{tabular}{|c|c|}
\hline & Peipeciefzed gyoed \\
\hline & Pelpedief goed \\
\hline & Peropecief reddijt \\
\hline & Pelpeciefnatig \\
\hline & Pelpecief dedt \\
\hline$\Delta$ & baivibi enhrookrmo \\
\hline 0 & now 23 \\
\hline 口 & nbo 4 \\
\hline
\end{tabular}

Figuur 3

Vraag en aanbod voor opleidingscategorieën hoger onderwijs, Noordwest Veluwe (2017-2022)

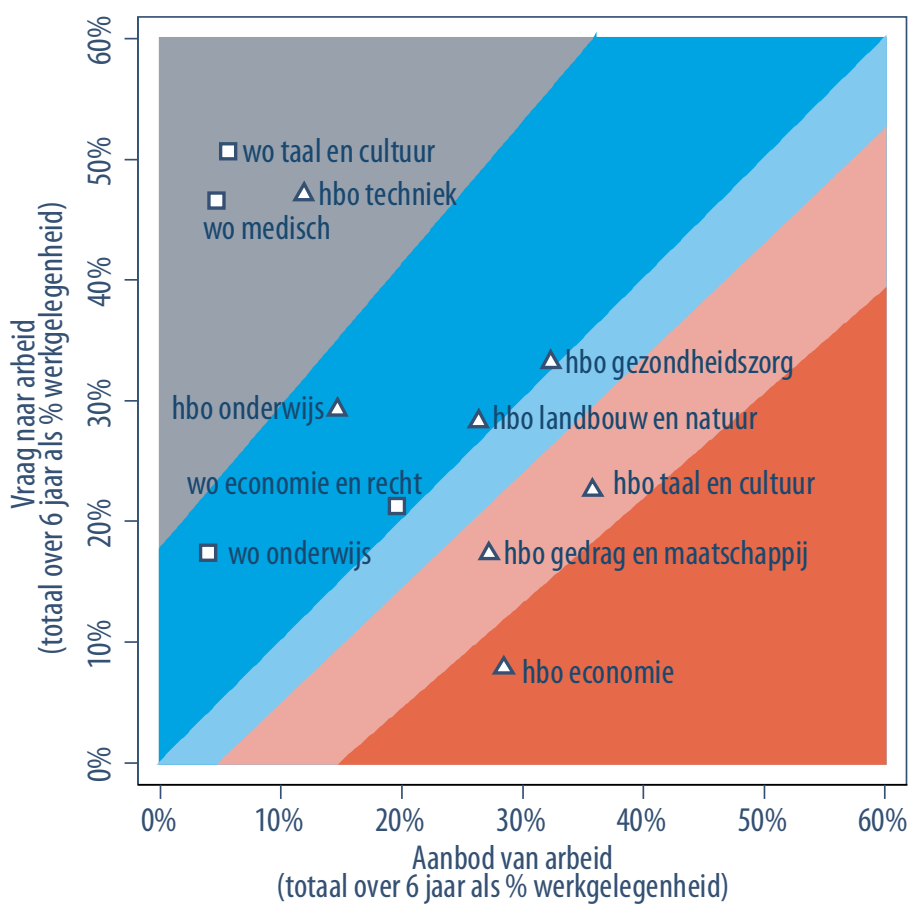

\begin{tabular}{|l|l|}
\hline & Perspectief zeer goed \\
\hline & Perspectief goed \\
& Perspectief redelijk \\
\hline & Perspectief matig \\
& Perspectief slecht \\
\hline$\Delta$ & hbo \\
$\square$ & wo \\
\hline
\end{tabular}

(totaal over 6 jaar als \% werkgelegenheid) 


\section{Figuur 4}

Arbeidsmarktperspectieven (ITA) versus specialisatie naar opleidingscategorie, Noordwest Veluwe

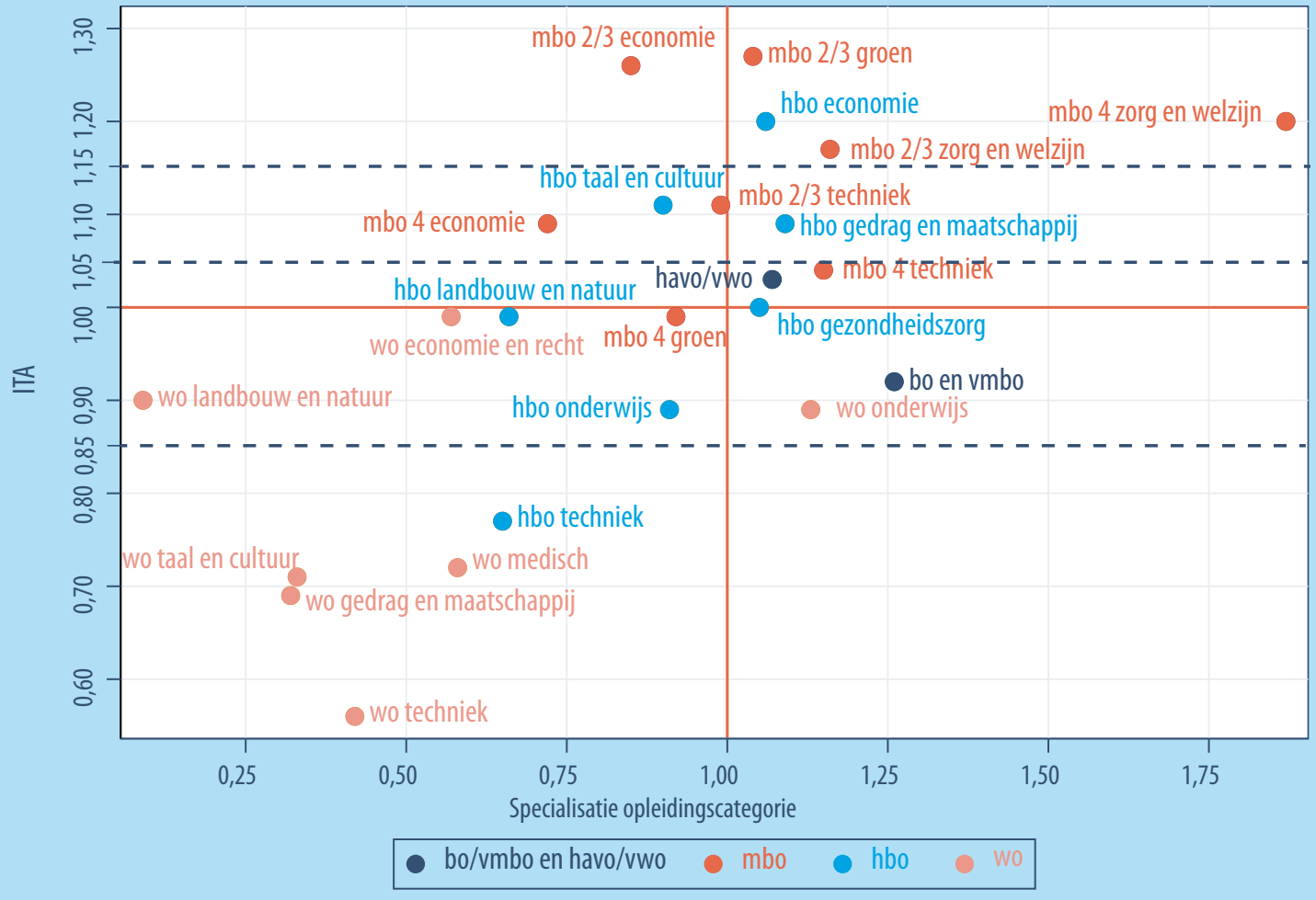




\section{Colofon}

( ) Researchcentrum voor Onderwijs en Arbeidsmarkt Niets uit deze uitgave mag op enige manier worden verveelvoudigd zonder voorafgaande schriftelijke toestemming van de directeur van het ROA.

Researchcentrum voor Onderwijs en Arbeidsmarkt

Maastricht University

School of Business and Economics

secretary-roa-sbe@maastrichtuniversity.nl

www.roa.n

\section{Vormgeving}

ROA secretariaat, Maastricht

juni 2018 